\title{
Isolasi Bakteri Pelarut Fosfat Genus Pseudomonas dari Tanah Masam Bekas Areal Perkebunan Karet di Kawasan Institut Teknologi Sumatera
}

\section{Isolation of Genus Pseudomonas, a Phosphate Solubilizing Bacteria from the Acid Soil of Institut Teknologi Sumatera's Former Rubber Plantation Site}

\author{
MUHAMMAD ASRIL ${ }^{1 *}$, YUNI LISAFITRI ${ }^{2}$ \\ ${ }^{1}$ Program Studi Biologi, Jurusan Sains, Institut Teknologi Sumatera. Jalan Terusan Ryacudu, Way Huwi, Jati Agung, Lampung \\ Selatan, 35365, Lampung, Indonesia \\ 2 Program Studi Teknik Lingkungan, Jurusan Infrastruktur dan Kewilayahan, Institut Teknologi Sumatera. Jalan Terusan Ryacudu, \\ Way Huwi, Jati Agung, Lampung Selatan, 35365, Lampung, Indonesia \\ Email: m.asril@bi.itera.ac.id
}

\begin{abstract}
Phosphorus $(P)$ is a nutrient that is needed by plants. The availability of this element is greatly influenced by soil $\mathrm{pH}$. As for ultisol soils classified as acid soils, most of the $P$ in the soil is not available and is bound to Fe and Al. Pseudomonas, a phosphate solubilizing bacteria are soil microbes that can improve the availability of $P$ in acid soils. This study aims to obtain Pseudomonas indigenous, a phosphate solubilizing bacteria from the acid soil formerly used by rubber plantations in the Institut Teknologi Sumatera. The study was conducted from April to June 2018 which included soil chemical analysis, isolation of the genus Pseudomonads on specific media, testing of phosphate solubility on solid Pikovskaya medium and simple pathogenicity test on potato tubers. The results showed that the sample soil was acidic with a $\mathrm{pH}$ of 4.09 with a P-availability of $0.78 \mathrm{ppm}$. From the soil samples, four potential isolates were obtained from the genus Pseudomonas, namely GSP 01, GSP 13, GSP 15 and GSP 06, with phosphate solubility indexes of $0.885,0.639,0.619$ and 0.568 , respectively. Isolates have the best phosphate solubilizing index on days 4 through 7 . The four potential isolates are not pathogenic, so they can be used as isolates to improve the availability of soil nutrients, especially phosphorus needed by plants.
\end{abstract}

Keywords: acid soil, phosphate solubilizing bacteria, phosphate availability, Pseudomonas

\begin{abstract}
ABSTRAK
Fosfor $(P)$ merupakan unsur hara yang sangat dibutuhkan oleh tanaman. Ketersediaan unsur ini sangat dipengaruhi oleh $\mathrm{pH}$ tanah. Pada jenis tanah ultisol yang digolongkan sebagai tanah masam, sebagian besar dari P di tanah dalam bentuk yang tidak tersedia untuk diserap oleh tanaman dan berikatan dengan Fe dan Al. Pseudomonas pelarut fosfat merupakan mikroba tanah yang dapat memperbaiki ketersediaan $\mathrm{P}$ pada tanah masam. Penelitian ini bertujuan untuk mendapatkan Pseudomonas pelarut fosfat indigenous dari tanah masam bekas lahan perkebunan karet di kawasan Institut Teknologi Sumatera. Penelitian dilaksanakan pada bulan April sampai Juni 2018 yang meliputi analisis kimia tanah, isolasi bakteri genus Pseudomonads pada medium spesifik, uji kemampuan pelarutan fosfat pada medium Pikovskaya padat serta uji patogenitas sederhana pada umbi kentang. Hasil penelitian menunjukkan bahwa tanah sampel bersifat masam dengan $\mathrm{pH}$ 4,09 dengan $\mathrm{P}$ tersedia sebesar $0,78 \mathrm{ppm}$. Dari sampel tanah diperoleh empat isolat potensial yang diperoleh merupakan genus Pseudomonas yaitu GSP 01, GSP 13, GSP 15 dan GSP 06, dengan indeks pelarutan fosfat berturut-turut sebesar $0,885,0,639,0,619$ dan 0,568 . Isolat memiliki indeks pelarutan fosfat terbaik pada hari ke-4 hingga hari ke-7. Keempat isolat potensial tidak bersifat patogen sehingga mampu dijadikan sebagai isolat yang dapat digunakan untuk memperbaiki ketersediaan unsur hara tanah terutama fosfor yang dibutuhkan oleh tanaman.
\end{abstract}

Kata kunci: bakteri pelarut fosfat, fosfat tersedia, Pseudomonas, tanah masam

\section{PENDAHULUAN}

\subsection{Latar Belakang}

Tanah masam seperti ultisol tersebar sangat luas di Indonesia terutama di Pulau Sumatera dan Kalimantan ${ }^{(1)}$. Penyebarannya yang luas menjadikan jenis tanah ini digunakan sebagai alternatif untuk areal pertanian. Permasalahan umum yang ditemukan pada tanah Ultisol adalah rendahnya $P$ tersedia karena tingginya fiksasi fosfat oleh beberapa mineral Al dan Fe. Proses pengikatan fosfat oleh beberapa mineral 
menyebabkan fosfat yang ada di tanah tidak dapat diserap oleh tanaman karena dalam bentuk fosfat terikat. Keadaan ini menyebabkan tanah menjadi tidak subur. Jenis tanah ini merupakan kondisi utama di wilayah Institut Teknologi Sumatera (ITERA). Saat ini, ITERA sedang melakukan percepatan pembangunan yang cukup progresif dan memberikan efek yang sangat baik terhadap kemajuan dan pemanfaatan lahan di ITERA. Seiiring dengan pembangunan infrastruktur, juga dibutuhkan kawasan hijau berupa penanaman tanaman disekitar wilayah ITERA diantaranya penghijauan dan pembangunan kebun raya ITERA. Akan tetapi, kondisi tanah ITERA yang berasal dari pelapukan batuan dan bekas lahan perkebunan karet ini memiliki ketersediaan unsur hara terbatas dan memiliki $\mathrm{pH}$ tanah yang sangat asam sehingga tidak mendukung dalam program penghijauan ini(2).

Program penghijauan lingkungan sangat dipengaruhi oleh produktivitas tanaman. Tanaman sangat tergantung pada nutrisi tanaman yang sebagian besar diambil dari dalam tanah, salah satunya fosfor ${ }^{(3)}$. Fosfor $(P)$ merupakan unsur utama makronutrien yang diperlukan untuk pertumbuhan dan perkembangan tanaman. Sebagian fosfor di tanah dalam bentuk yang tidak dapat diserap oleh tanaman ( $P$ tidak terlarut) sehingga tanaman hanya mampu menyerap mono atau dibasik fosfat, organik fosfat atau bentuk fosfat yang tidak terlarut. Bentuk fosfat ini harus dimineralisasi atau dilarutkan oleh mikroorganisme yaitu bakteri pelarut fosfat ${ }^{(4)}$. Tanah yang tidak mengandung bakteri pelarut fosfat mengakibatkan jumlah fosfat yang diserap oleh tanaman cenderung sangat rendah sehingga mengakibatkan tanah tersebut menjadi tidak subur(5). Hal ini dapat terlihat dari vegetasi di lahan ITERA cenderung hanya ditumbuhi oleh semak, sehingga perlu ada perlakuan atau manipulasi ekologi untuk meningkatkan pertumbuhan tanaman lainnya.

Bakteri pelarut fosfat diketahui mampu melarutkan $\mathrm{P}$ dengan melepaskan senyawa $\mathrm{P}$ melalui mekanisme pembentukan khelat, reaksi pertukaran, dan produksi asam organik ${ }^{(6)}$. Pengaruh mikroorganisme pelarut fosfat terhadap tanaman, tidak hanya disebabkan oleh kemampuannya dalam meningkatkan ketersediaan $\mathrm{P}$ tetapi juga karena kemampuannya dalam menghasilkan zat pengatur tumbuh, terutama oleh mikroorganisme yang hidup pada permukaan akar $^{(3)}$. Pemanfaatan mikroba tanah indigenous yang potensial dari tanah masam berpotensi untuk dilakukan dalam rangka mendukung program penghijauan yang dilakukan oleh ITERA dan cara ini bersifat ramah lingkungan dari pada cara yang sering digunakan selama ini berupa pemupukan yang tidak ramah lingkungan(1). Bakteri yang potensial dalam melarutkan fosfat akan mengalami penghambatan aktivitasnya bila diintroduksikan pada habitat yang bukan berasal dari sumber aslinya (indigenous). Selain itu, faktor kemasaman $(\mathrm{pH})$ suatu lingkungan merupakan faktor pembatas aktivitas dari bakteri pelarut fosfat ${ }^{(7)}$.

Beberapa kelompok bakteri seperti Pseudomonas, Bacillus, dan Rhizobium merupakan bakteri pelarut fosfat yang paling potensial. Kelompok bakteri Pseudomonas paling banyak ditemukan sebagai bakteri pelarut fosfat terbaik. Jenis Pseudomonas yang umumnya diketahui mampu melarutkan $P$ terbaik antara lain $P$. fluoresces ${ }^{(8)}, P$. psychrotolerance $^{(9)}, \quad P$. $\quad$ cepaceae $^{(7)}, \quad P$. aeruginosa dan $P$. oryzihabitans ${ }^{(10)}$. Oleh karena itu, pencarian isolat bakteri pelarut fosfat indigenous genus Pseudomonas dari tanah masam ini sangat berguna untuk memperoleh bakteri potensial yang cocok diaplikasikan pada lahan ultisol di ITERA serta untuk mendukung program penghijauan dan pembangunan kebun raya ITERA demi mewujudkan ITERA Forest Campus.

\subsection{Tujuan Penelitian}

Tujuan dari penelitian ini adalah untuk memperoleh bakteri pelarut fosfat indigenous genus Pseudomonas dari tanah masam bekas lahan perkebunan karet yang berpotensi untuk meningkatkan kesuburan tanah, terutama di kawasan ITERA.

\section{BAHAN DAN METODE}

\subsection{Bahan}

Bahan yang digunakan dalam penelitian ini adalah tanah (top soil) yang dikoleksi dari tanah bekas lahan perkebunan karet PTPN VII, Desa Way Hui, Kecamatan Jati Agung, Lampung Selatan. Tanah diambil dengan kedalaman 15 $\mathrm{cm}$ dari permukaan. Sampel tanah yang telah dikoleksi dimasukkan kedalam kantok plastik dan disimpan di dalam lemari pendingin.

\subsection{Metode}

Penelitian ini dilakukan di Kawasan Embung F, Institut Teknologi Sumatera. Kawasan ini merupakan lahan bekas perkebunan karet PTPN VII, Desa Way Hui, Kecamatan Jati Agung, Lampung Selatan dan Laboratorium Biologi, Institut Teknologi Sumatera. Penelitian dilaksanakan selama 4 bulan dimulai dari bulan April sampai dengan Juli 2018. 


\subsubsection{Pengambilan sampel tanah}

Pengambilan sampel tanah dilakukan dengan metode Purposive Random Sampling pada permukaan tanah (top soil) dengan kedalaman $15 \mathrm{~cm}$. Sampel tanah diambil saat sore hari pada pukul 16.00-18.00 WIB di koordinat $5^{\circ} 22^{\prime} 5.99^{\prime \prime} \mathrm{LS}, 105^{\circ} 19^{\prime} 12.67^{\prime \prime}$ BT.

\subsubsection{Analisis kimia tanah}

Sampel tanah yang telah diambil dilakukan analisis kimia tanah. Pengukuran kandungan kimia tanah yang dianalisis ialah kandungan total fosfor (P), P-tersedia, Aluminium (Al), Besi $(\mathrm{Fe})$, Mangan (Mn), Magnesium (Mg), Kalsium (Ca) dan $\mathrm{pH}$ tanah.

\subsubsection{Isolasi bakteri genus Pseudomonas dari sampel tanah}

Proses isolasi bakteri Pseudomonas pelarut fosfat diawali dengan pengkayaan $10 \mathrm{~g}$ sampel tanah pada $90 \mathrm{ml}$ medium Nutrien Broth yang diperkaya dengan $5 \% \mathrm{Ca}_{3}\left(\mathrm{PO}_{4}\right)_{2}$ dan diinkubasi dalam inkubator goyang pada kecepatan 120 rpm selama 24 jam pada suhu ruang. Campuran sampel dibuat pegenceran serial sampai $10^{-4}$. Sebanyak 0.1 dari pengenceran $10^{-2}$ sampai $10^{-}$ ${ }^{4}$ disebar di atas permukaan medium Glutamate Starch Phenol (GSP) Agar yang terdiri dari (10 g Sodium L-glutamate, $20 \mathrm{~g}$ Starch, $2 \mathrm{~g}$ Potassium dihidrogen phosphate, $0,5 \mathrm{~g}$ Magnesium sulfate, 0,36 Fenol red, $12 \mathrm{~g}$ Agar dilarutkan dalam 1 liter akuades dengan $\mathrm{pH}$ 7,2). Media ini merupakan media selektif untuk menumbuhkan kelompok bakteri Pseudomonas dan Aeromonas. Koloni bakteri yang berwarna digolongkan dalam genus Pseudomonas, sedangkan koloni berwana kuning digolongkan dalam kelompok Aeromonas. Koloni yang tumbuh berwarna merah dan kuning dimurnikan dengan metode gores kuadran pada medium Nutrient Agar (NA) untuk mendapatkan koloni tunggal dan dikarakterisasi morfologi makroskopisnya.

\subsubsection{Pengujian kemampuan bakteri genus Pseudomonas dalam melarutkan fosfat}

Pengujian kemampuan bakteri dalam melarutkan fosfat dilakukan dengan cara isolat bakteri yang telah murni, ditumbuhkan pada medium Pikovskaya padat yang mengandung

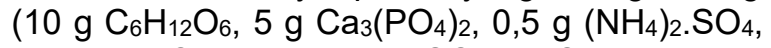
$0,2 \mathrm{~g} \mathrm{KCl}, 0,1 \mathrm{~g} \mathrm{MgSO}_{4} .7 \mathrm{H}_{2} \mathrm{O}, 0,002 \mathrm{~g}$ $\mathrm{MnSO}_{4} .7 \mathrm{H}_{2} \mathrm{O}, 0,002 \mathrm{~g} \mathrm{FeSO}_{4} .7 \mathrm{H}_{2} \mathrm{O}, 0,1 \mathrm{~g} \mathrm{NaCl}$, $0,5 \mathrm{~g}$ yeast extract, $20 \mathrm{~g}$ agar dilarutkan dalam $1000 \mathrm{ml}$ akuades dengan $\mathrm{pH} 7,0$ ), dengan cara ditotol dan diinkubasi selama 7 hari pada suhu $30{ }^{\circ} \mathrm{C}$. Pertumbuhan koloni bakteri pelarut $\mathrm{P}$ ditandai dengan pembentukan zona bening disekitar koloni. Zona bening yang terbentuk di sekitar koloni diukur dan dihitung indeks pelarutan (IP) $\mathrm{P}$ pada masing-masing koloni untuk mengetahui daya degradasi bakteri terhadap $\mathrm{P}$ dengan persamaan berikut ${ }^{(11)}$ :

IP: $\frac{\text { diameter zona bening }(\mathrm{mm}) \text { - diameter koloni }(\mathrm{mm})}{}$ diameter koloni $(\mathrm{mm})$

\subsubsection{Pengujian patogenitas isolat bakteri potensial}

Isolat bakteri yang memiliki indeks pelarut fosfat tertinggi dilakukan uji patogenitas sederhana pada umbi kentang yang telah dimodifikasi ${ }^{(12)}$. Metode uji patogenitas ini merupakan modifikasi dari Lelliot dan Stead ${ }^{(13)}$. Uji ini bertujuan untuk melihat kemampuan pektinolitik isolat bakteri. Aktivitas pektinolitik merupakan indikasi awal isolat bakteri mampu merusak pektin (berupa lesi pada umbi kentang) yang terdapat pada dinding sel tanaman. Pengujian pembusukan kentang ini dilakukan dengan cara menginokulasikan bakteri dengan cara ditusuk pada bagian tengah umbi kentang yang telah dicuci dengan air mengalir. Umbi kentang yang telah diinokulasikan bakteri diinkubasi dalam cawan petri yang telah diberikan kertas saring dan air steril untuk menjaga kelembapan. Aktivitas pektinolitik diamati selama 2-3 hari dan diinkubasi pada suhu ruang. Reaksi positif dari isolat ditunjukkan dengan adanya pembusukan pada bagian tengah umbi kentang yang diinokulasikan bakteri uji. Reaksi positif tersebut menandakan bahwa isolat tersebut terindikasi sebagai patogen pada tanaman dan tidak dapat dijadikan sebagai kandidat isolat potensial.

\section{HASIL DAN PEMBAHASAN}

\subsection{Analisis Kimia Tanah}

Sampel tanah yang digunakan sebagai bahan uji dilakukan analisis kimia tanah sebagai parameter kondisi sampel tanah dan impilkasinya terhadap keragaman bakteri serta tingkat kesuburan tanah. Hasil analisis kimia tanah menunjukkan bahwa jenis tanah dikategorikan dalam tanah ultisol masam dengan $\mathrm{pH} 4,09$. Tanah ultisol memiliki ciri-ciri, bahan induk tanah adalah batuan sedimen masam dan peka terhadap erosi. Ultisol umumnya berwarna kuning kecoklatan hingga merah. Reaksi tanah ultisol pada umumnya masam hingga sangat masam $(\mathrm{pH} 5,0-3,10)^{(14)}$. Asril dan Lisafitri(2) juga melaporkan bahwa $\mathrm{pH}$ tanah dikawasan ITERA berada pada $\mathrm{pH} 4,09$ 5,4 . Selain kondisi $\mathrm{pH}$ yang sangat asam, kadar $\mathrm{P}$ tersedia juga sangat rendah yaitu $0,78 \mathrm{ppm}$ (Tabel 1). Hal ini terlihat bahwa fosfat yang 
dapat diserap oleh tanaman sangat rendah jika dibandingkan dengan $\mathrm{P}$ total sebesar 9,98 ppm. Kadar $\mathrm{P}$ tersedia ini juga sangat rendah jika dibandingkan dengan standar $P$ tersedia $(>10$ ppm). Hal ini menyebabkan sulitnya tanaman dapat tumbuh dengan baik pada kondisi tanah dengan konsentrasi $\mathrm{P}$ tersedia yang rendah.

Tabel 1. Karakteristik Tanah

\begin{tabular}{lcc}
\hline \multicolumn{1}{c}{ Parameter } & Standar & Nilai \\
\hline $\mathrm{pH}$ & $5,5-7,5$ & 4,09 \\
P-tersedia $(\mathrm{ppm})$ & $>10 \mathrm{ppm}$ & 0,78 \\
P-total $(\mathrm{ppm})$ & - & 9,98 \\
Fe-dd $(\mathrm{ppm})$ & - & 34,24 \\
$\mathrm{Al}-\mathrm{dd}(\mathrm{me} / 100 \mathrm{~g})$ & $21-30 \mathrm{me} / 100 \mathrm{gr})$ & 1,15 \\
$\mathrm{Ca}-d d(\mathrm{me} / 100 \mathrm{~g})$ & $2 \mathrm{me} / 100 \mathrm{gr}$ & 1,04 \\
$\mathrm{Mg}-\mathrm{dd}(\mathrm{me} / 100 \mathrm{~g})$ & $\geq 25 \mathrm{me} / 100 \mathrm{gr}$ & 0,68 \\
\hline
\end{tabular}

Ketersediaan jumlah fosfat tersedia di tanah dipengaruhi oleh adanya logam lainnya seperti Fe dan Al yang mampu berikatan $\mathrm{P}$. Tanah yang diujikan memiliki kandungan $\mathrm{Fe}$-dd (Fe yang akan berikatan dengan fosfat) yang cukup tinggi 34,24 ppm sehinga fosfat terikat dalam bentuk Fe-P cukup tinggi yang menyebabkan fosfat tersedia didalam tanah menjadi sedikit. Hal ini menjadi salah satu penyebab kondisi sampel tanah menjadi asam. Tanah masam jenis ultisol diketahui keracunan $\mathrm{Al}$ dan $\mathrm{Fe}^{(15)}$. Kondisi ini juga didukung dengan hasil bahwa logam $\mathrm{Ca}$ dan Mg cukup rendah sehingga tidak terlalu banyak $\mathrm{P}$ berikatan dengan $\mathrm{Ca}$ dan $\mathrm{Mg}$. Rendahnya kandungan $\mathrm{Ca}$ dan $\mathrm{Mg}$ juga menjadi salah satu penyebab $\mathrm{pH}$ tanah tidak dapat naik ke kondisi $\mathrm{pH}$ normal. Jumlah $\mathrm{Ca}$ dan $\mathrm{Mg}$ tertukar (kondisi dapat diserap oleh tanaman) yang cukup rendah disebabkan oleh proses pencucian. Ca dan $\mathrm{Mg}$ tertukar akan larut dalam air waktu pencucian (hujan).

\subsection{Jumlah Total Bakteri Genus Pseudomonas dan Aeromonas dari Sampel Tanah}

Hasil isolasi bakteri genus Pseudomonas dan Aeromonas dari sampel tanah diperoleh bahwa jumlah populasi genus Pseudomonas lebih tinggi daripada genus Aeromonas (Tabel 2). Genus Pseudomonas berjumlah $44 \times 10^{5}$ cfu/g sampel tanah. Jumlah populasi bakteri Pseudomonas yang diperoleh sama dengan hasil isolasi pada tanah perkebunan karet milik PTPN VII Bandar Lampung yang berlokasi di Tanjung Bintang yaitu 13 x $10^{5} \mathrm{cfu} / \mathrm{g}$ sampel $\operatorname{tanah}^{(16)}$. Hasil ini menunjukkan bahwa kondisi tanah di perkebunan karet milik PTPN VII memiliki kesamaan jumlah populasi mikroba walaupun berbeda lokasi. Kondisi ini disebabkan karena kondisi $\mathrm{pH}$ yang asam pada tanah yang dijadikan sebagai sampel penelitian serta perlakuan pemupukan pada perkebunan karet pada masa lampau yang mempengaruhi terhadap distribusi kelimpahan bakteri.

Tabel 2. Jumlah populasi Genus Pseudomonas dan Aeromonas dari sampel tanah

\begin{tabular}{lc}
\hline \multicolumn{1}{c}{ Genus } & $\begin{array}{c}\text { Jumlah } \\
\text { (cfu/g) }\end{array}$ \\
\hline Pseudomonas & $44 \times 10^{5}$ \\
Aeromonas & $18 \times 10^{4}$ \\
\hline
\end{tabular}

Berdasarkan total populasi tersebut diperoleh 16 isolat bakteri yang terdiri dari dua belas $(75 \%)$ isolat genus Psedomonas dan empat isolat (25\%) genus Aeromonas dengan karakter yang bervariasi (Tabel 3). Hal ini menunjukkan bahwa genus Pseudomonas mendominasi populasi pada tanah yang dijadikan sampel. Sedangkan keberadaan Aeromonas di tanah masam berdasarkan taksonomi polyphasic sebesar $5,71 \%{ }^{(17)}$. Pseudomonas di tanah sangat dominan dan berlimpah terutama $P$. rescens. Kelimpahan Pseudomonas di rizosfer dan tanah erat kaitannya dengan kemampuan bakteri ini dalam menghasilkan antifungal ${ }^{(18)}$ dan senyawa lainnya.

Keberadaan komunitas Pseudomonas di tanah dipengaruhi oleh sejarah dan manajemen penggunaan lahan pada masa lampau(21). Faktor intrinsik tanah dan kondisi iklim lingkungan juga berperan terhadap komunitas Pseudomonas di tanah ${ }^{(18)}$. Hal ini didukung oleh lokasi lahan dalam pengambilan sampel merupakan lahan bekas perkebunan karet yang telah mengalami pemupukan bertahun-tahun dan memiliki $\mathrm{pH}$ yang sangat asam dan keracunan Fe. Kondisi iklim lingkungan selama di lokasi pengambilan sampel yaitu suhu udara di rentang $25-28{ }^{\circ} \mathrm{C}$, kelembapan pada rentang $44,79-86,65 \%^{(2)} \quad$ menunjukkan kondisi lingkungan yang toleran terhadap keberadaan kelompok Pseudomonas. Berbagai kondisi lingkungan dan kondisi tanah dari berbagai laporan menunjukkan bahwa bakteri Pseudomonas merupakan bakteri yang memiliki tingkat toleransi yang tinggi dengan berbagai kondisi (Tabel 4). 
Tabel 3. Karakter morfologi isolat hasil isolasi

\begin{tabular}{lcc}
\hline Kode Isolat & Genus & Karakter \\
\hline GSP 01 & Pseudomonas & Bulat kecil dan berwarna kuning \\
GSP 02 & Pseudomonas & Bulat dan transparan \\
GSP 03 & Pseudomonas & Bulat dan putih mengkilat \\
GSP 04 & Aeromonas & Bulat dan berwarna kuning \\
GSP 05 & Aeromonas & Bulat dan transparan \\
GSP 06 & Pseudomonas & Bulat dan berwarna putih kekuningan \\
GSP 07 & Pseudomonas & Bulat dan berwarna putih kekuningan \\
GSP 08 & Aeromonas & Bulat, berwarna kuning dan pertumbuhan lambat \\
GSP 09 & Aeromonas & Bulat, putih, dan pertumbuhan lambat \\
GSP 10 & Pseudomonas & Bulat dan berwarna putih gelap \\
GSP 11 & Pseudomonas & Bulat dan berwarna putih susu \\
GSP 12 & Pseudomonas & Bulat, berwarna putih kecoklatan serta memiliki warna \\
& kemerahan pada tepi koloni \\
GSP 13 & Pseudomonas & Bulat, putih pekat, pertumbuhan sangat tebal dan \\
GSP 14 & Pseudomonas & Bulliki kecintik hitam pada bagian tengah koloni \\
GSP 15 & Pseudomonas & Bulat kecil dan berwarna putih kekuningan \\
GSP 16 & Pseudomonas & Bulat transparan \\
\hline
\end{tabular}

Tabel 4. Kondisi tanah dan lingkungan yang cocok untuk habitat Pseudomonas

\begin{tabular}{|c|c|}
\hline Kondisi tanah & Jenis \\
\hline Tanah Masam & Pseudomonas sp. Strain DSMZ 13134(19) \\
\hline Tanah terkontaminasi logam & Pseudomonas sp. ${ }^{(20)}$ \\
\hline Tanah padang rumput & $P$. fluorescens LCSAO- TU2 ${ }^{(21)}$ \\
\hline $\begin{array}{l}\text { Tanah dengan kadar } \mathrm{P} \text { rendah (Tanah } \\
\text { merah }(0,3 \mathrm{ppm}) \text { dan tanah kuning }(0,4 \\
\text { ppm)) }\end{array}$ & P. arvilla(22) \\
\hline $\begin{array}{l}\text { Tanah dengan kadar } P \text { rendah Tanah } \\
\text { kuning }(0,4 \mathrm{ppm}) \text { dan tanah coklat kuning } \\
(0,2 \mathrm{ppm})\end{array}$ & P. putida (22) \\
\hline $\begin{array}{l}\text { Tanah dengan kadar } P \text { tinggi tanah coklat } \\
(2,7 \mathrm{ppm}) \text {, tanah wiep ( } 3,9 \mathrm{ppm})\end{array}$ & P. striata ${ }^{(22)}$ \\
\hline $\begin{array}{l}\text { Tanah Gambut }\left(\mathrm{pH} 4,91 \text {, suhu tanah } 29^{\circ} \mathrm{C}\right. \\
\left.\text { dan } 30{ }^{\circ} \mathrm{C}\right) \text { dan Pod soil Merah kuning } \\
\left(\text { PMK) }\left(\mathrm{pH} 5,15 \text {, suhu tanah } 30^{\circ} \mathrm{C} \text { dan }\right.\right. \\
\left.\text { suhu udara } 30^{\circ} \mathrm{C}\right) \text {. }\end{array}$ & $\begin{array}{c}\text { Psedomonas BPFGM7 dan Pseudomonas } \\
\text { BPFPMK3(23) }\end{array}$ \\
\hline
\end{tabular}

\subsection{Kemampuan Bakteri Melarutkan Fosfat secara Kualitatif}

Dari enam belas isolat bakteri yang diperoleh, terdapat sepuluh isolat bakteri yang mampu membentuk zona bening pada medium Pikovskaya. Zona bening tersebut menunjukkan bahwa bakteri tersebut mampu melarutkan fosfat. Terbentuknya zona bening di sekitar koloni menunjukkan, bahwa isolat tersebut mampu menghasilkan asam asam organik yang mampu berikatan dengan ion $\mathrm{Ca}$ - membentuk senyawa $\mathrm{Ca}_{3}\left(\mathrm{PO}_{4}\right)_{2}$ pada media Pikovskaya dan membebaskan ion $\mathrm{H}_{2} \mathrm{PO}_{4}{ }^{-}$sehingga membentuk area yang berwarna lebih jernih(24). Jumlah isolat bakteri yang mampu melarutkan fosfat pada sampel tanah masih dalam jumlah terbatas. Asril dan Lisafitri( ${ }^{(2)}$ melaporkan bahwa populasi bakteri pelarut fosfat di lokasi titik pengambilan sampel yang sama hanya berjumlah $14,2 \times 10^{4} \mathrm{cfu} / \mathrm{g}$. Populasi bakteri fosfat didalam tanah dipengaruhi oleh $\mathrm{pH}$ tanah. $\mathrm{pH}$ tanah sampel sebesar 4,09 merupakan faktor utama yang menyebabkan jumlah isolat bakteri pelarut fosfat dari sampel terbatas. Faktor kemasaman suatu lingkungan merupakan faktor pembatas aktivitas dari bakteri pelarut fosfat ${ }^{(9)}$.

Dari enam belas isolat bakteri yang diperoleh, terdapat sepuluh isolat bakteri yang mampu membentuk zona bening pada medium Pikovskaya (Gambar 1). Zona bening tersebut menunjukkan bahwa bakteri tersebut mampu melarutkan fosfat. Isolat bakteri yang tidak mampu membentuk zona bening yaitu isolat GSP 02, GSP 05, GSP 09, GSP 11, GSP 12 dan GSP 16. Dari keenam isolat tersebut terdapat dua isolat yang merupakan genus 
Aeromonas. Dari sepuluh isolat bakteri yang memiliki kemampuan melarutkan fosfat menunjukkan bahwa isolat genus Pseudomonas memiliki indeks pelarutan lebih tinggi daripada dua isolat genus Aeromonas lainnya. Isolat bakteri genus Pseudomonas yang memiliki indeks pelarutan fosfat pada media pikovskaya yaitu GSP 13, GSP 01, GSP 06 dan GSP 15. Indeks pelarutan fosfat masing-masing isolat tersebut secara berurutan yaitu $0,639,0,619$, 0,513 dan 0,473 selama 7 hari masa inkubasi (Gambar 2).

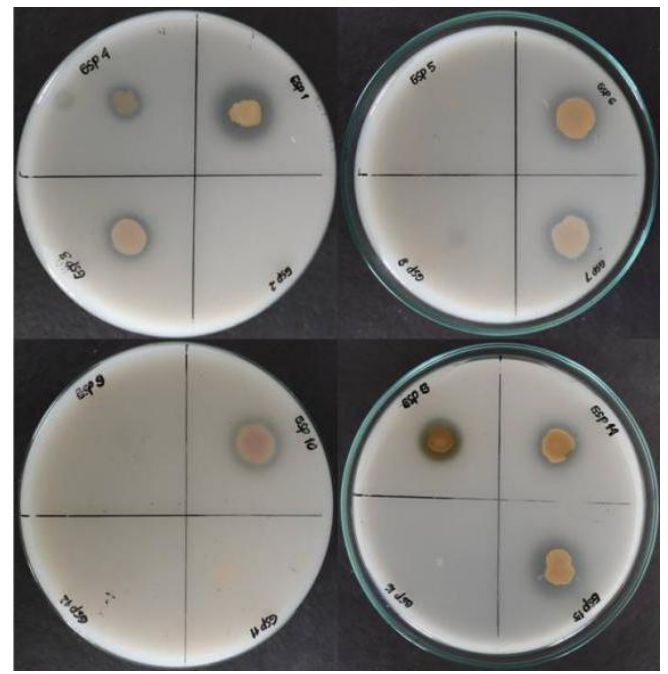

Gambar 1. Zona bening isolat bakteri pada medium Pikovskaya selama 7 hari masa inkubasi

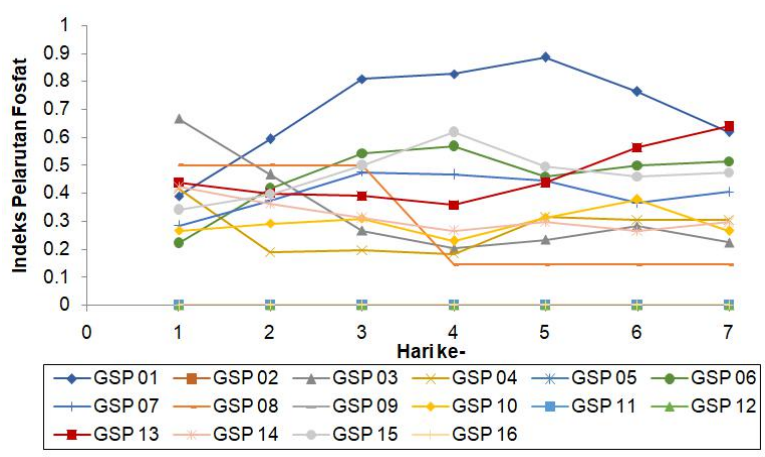

Gambar 2. Indeks pelarutan fosfat pada medium Pikovskaya selama 7 hari masa inkubasi

Pada umumnya, bakteri jenis Pseudomonas merupakan jenis bakteri yang dikenal sebagai pelarut fosfat terbaik selain Bacillus dan Rhizobium. Jenis Pseudomonas tersebut antara lain, P. psychrotolerance ${ }^{(9)}, P$. cepaceae ${ }^{(7)}, P$. aeruginosa dan $P$. oryzihabitans ${ }^{(10)}, P$. helmanticensis sp. nov ${ }^{(25)}$, serta $P$. fluorescens ${ }^{(8)}$. Bakteri Pseudomonas banyak dilaporkan sebagai bakteri yang memiliki konsentrasi pelarutan fosfat tertinggi di rhizosfer ${ }^{(26)}$ bahkan salah satu spesies Pseudomonas FBJ6 merupakan pelarut fosfat yang paling efisien sebagai pupuk hayati ${ }^{(27,28)}$. Penggunaan Pseudomonas seperti $P$. fluorescens di tanah pertanian sangat tinggi dan memiliki kemampuan sebagai plant growth promoting rhizobacteria (PGPR) untuk dikembangkan sebagai biofertilizer dan bioinokulan untuk tanaman ${ }^{(29)}$. Hal ini berbanding terbalik dengan keberadaan spesies Aeromonas asal tanah sebagai pelarut fosfat. Laporan tentang keberadaan Aeromonas sebagai pelarut fosfat ditanah hanya dari spesies $A$. hydrophila ${ }^{(30)}$.

Selain itu, Indeks pelarutan fosfat keempat isolat Pseudomonas bervariasi tergantung masa inkubasinya. Keempat isolat memiliki indeks pelarutan fosfat tertinggi pada hari ke- 4 hingga hari ke-7. Berdasarkan masa inkubasi, isolat bakteri dengan indeks pelarutan fosfat tertinggi yaitu GSP 01, GSP 06, GSP 13 dan GSP 15 (Tabel 5). Pembentukan zona jernih dari masing-masing isolat, mulai terbentuk sejak hari ke-2 sampai $8^{(31)}$. Kemampuan pembentukan zona bening tergantung pembelahan diri bakteri selama fase logaritmik dan dipengaruhi oleh jenis bakteri dan faktor lingkungan seperti substrat, suhu, $\mathrm{pH}$ dan lainnya.

Tabel 5. Waktu inkubasi isolat dengan indeks pelarutan fosfat tertinggi

\begin{tabular}{cccc}
\hline $\begin{array}{c}\text { Kode } \\
\text { Isolat }\end{array}$ & Genus & $\begin{array}{c}\text { Indeks } \\
\text { pelarutan } \\
\text { fosfat }\end{array}$ & Waktu inkubasi \\
\hline GSP 01 & Pseudomonas & 0.885 & Hari ke 5 \\
GSP 06 & Pseudomonas & 0.568 & Hari ke 4 \\
GSP 13 & Pseudomonas & 0.639 & Hari ke 7 \\
GSP 15 & Pseudomonas & 0.619 & Hari ke 4 \\
\hline
\end{tabular}

\subsection{Patogenitas Isolat Potensial}

Patogenitas suatu isolat potensial sangat penting untuk diketahui. Uji sederhana dapat dilakukan dengan menggunakan uji pembusukan kentang (uji pektinolitik). Sebanyak empat isolat genus Pseudomonas (GSP 01, GSP 06, GSP 13 dan GSP 15) yang memiliki indeks pelarutan fosfat tertinggi menunjukkan hasil negatif dalam membusukkan kentang (Tabel 6) (Gambar 3). Uji ini bertujuan untuk melihat aktivitas pektinolitik bakteri yang digunakan mampu merusak pektin yang terdapat pada umbi kentang. Umbi kentang menjadi salah satu sampel model untuk pengujian degradasi pektin yang biasanya ditemukan pada dinding sel tanaman. Indikasi bakteri digolongkan sebagai patogen tanaman yaitu terjadinya lesi pada kentang yang diujikan (12). Penggunaan kentang sebagai inang model dikarenakan kentang merupakan inang alternatif yang mampu memberikan informasi terhadap patogenitas suatu bakteri uji(32). Bakteri yang 
menyebabkan busuk lunak pada tanaman dan bersifat patogen tergolong kedalam bakteri yang bersifat soft rot ${ }^{(33)}$. Berdasarkan hasil tersebut menunjukkan bahwa keempat isolat bakteri potensial tidak bersifat patogen terhadap tanaman apabila diaplikasikan pada tanah dan tanaman.

Tabel 6. Uji pembusukan kentang (uji pektinolitik) isolat terpilih

\begin{tabular}{ccc}
\hline $\begin{array}{r}\text { Kode } \\
\text { Isolat }\end{array}$ & Genus & $\begin{array}{c}\text { Uji } \\
\text { pembusukan } \\
\text { kentang }\end{array}$ \\
\hline GSP 01 & Pseudomonas & Negatif \\
GSP 06 & Pseudomonas & Negatif \\
GSP 13 & Pseudomonas & Negatif \\
GSP 15 & Pseudomonas & Negatif \\
\hline
\end{tabular}

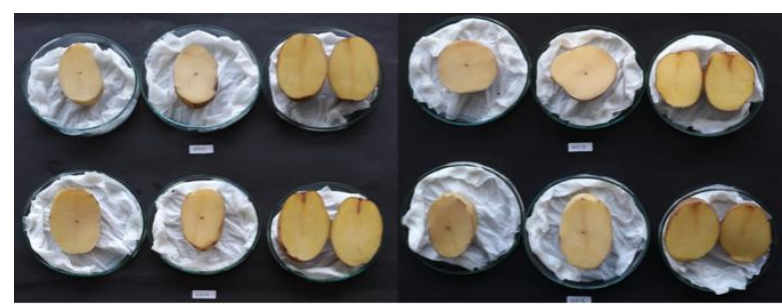

Gambar 3. Uji patogenitas pada umbi kentang

\section{KESIMPULAN}

Sepuluh isolat bakteri kelompok Pseudomonads pelarut fosfat berhasil diperoleh dari tanah masam bekas lahan perkebunan karet di Kawasan ITERA. Empat isolat potensial melarutkan fosfat pada media Pikovskaya merupakan genus Pseudomonas yaitu GSP 01, GSP 13, GSP 15 dan GSP 06, masing-masing memiliki indeks pelarutan fosfat berturut-turut sebesar 0,885, 0,639, 0,619 dan 0,568. Variasi indeks pelarutan fosfat tergantung masa inkubasi isolat. Masa inkubasi dengan indeks pelarutan fosfat terbaik yaitu hari ke-4 hingga hari ke-7. Keempat isolat potensial tidak mampu membusukkan kentang sebagai pengujian sederhana patogenitas suatu bakteri. Isolat potensial ini mampu dijadikan sebagai kandidat bakteri yang dapat digunakan untuk memperbaiki ketersediaan unsur hara tanah masam terutama fosfat tersedia yang dibutuhkan oleh tanaman.

\section{PERSANTUNAN}

Penulis menyampaikan terima kasih kepada Institut Teknologi Sumatera atas dukungan pembiayaan penelitian ini melalui Program Hibah Penelitian Mandiri SMART ITERA kepada Muhammad Asril dengan Nomor Kontrak Penelitian: 134s/IT9.C1/PP/2018.

\section{DAFTAR PUSTAKA}

1. Lubis, A., Ani, N., \& Sofian, A. (2016). Pemberian jamur pelarut fosfat asal isolat tanah ultisol masam padang bulan medan untuk meningkatkan pertumbuhan tanaman jagung (Zea mays L.). Agrium, 20(2), 96-100.

2. Asril, M., \& Lisafitri, Y. (2019). Amount of soil phosphate solubilizing bacteria in the reservoir of itera and its environmental conditions. IOP Conference Series: Earth and Environmental Science, 258, DOI: 10.1088/17551315/258/1/012026.

3. Roni, N. G., Witariadi, N. M., Candraasih, K. N. N., \& Siti, N. W. (2013). Pemanfaatan bakteri pelarut fosfat untuk meningkatkan produktivitas kudzu tropika (Pueraria phaseoloides Benth.). Pastura, 3(1), 13-16.

4. Ramaekers, L., Remans, R., Rao, I. M., Blair, M. W \& Vanderleyden, J. (2010). Strategies for improving phophorus acquisition efficiency of crop plants. Field Crops Research, 117 (2010), 167-176.

5. Ilham, Darmayasa, I. B. G., Nurjaya, I. G. M. O., \& Kawuri, R. (2014). Isolasi dan identifikasi bakteri pelarut fosfat potensial pada tanah konvensional dan tanah organik. Jurnal Simbiosis II, 2(1), 173-183.

6. Chen, Y. P., Rekha, P. D., Arun, A. B., Shen, F. T., Lai, W. A., \& Young, C. C. (2006). Phosphate solubilizing bacteria from subtropical and their tricalcium phosphate solubilizing ability. Applied Soil and Ecology, 34(1), 33-41.

7. Setiawati, M. R., \& Pranoto, E. (2015). Perbandingan beberapa bakteri pelarut fosfat eksogen pada tanah andisol sebagai areal pertanaman teh dominan di indonesia. Jurnal Penelitian Teh dan Kina, 18(2), 159-164.

8. Sharma, S., Kumar, V., \& Tripathi, R. B. (2011). Isolation of phosphate solubilizing microorganism (psms) from soil. Journal of Microbiology and Biotechnology Research, 1(2), 90-95.

9. Fitriyanti, D., Mubarik, N. R., \& Tjahjoleksono, A. (2017). Characterization of phosphate solubilizing bacteria and nitrogen fixing bacteria from limestone mining region. Malaysian Journal of Microbiology, 13(3), 147155.

10.Liu, Z., Li, Y. C., Zhang, S., Fu, Y., Fan, X., Patel, J. S., \& Zhang, M. (2015). Characterization of phosphate-solubilizing bacteria isolated from calcareous soils. Applied Soil Ecology, 96(2015), 217-224. DOI:10.1016/j.apsoil.2015.08.003 
11. Mursyida, E. (2015). Isolasi dan identifikasi bakteri pelarut fosfat dan kalium dari kawasan sekitar tambang batu kapur Cirebon. [tesis]. Bogor (ID): Institut Pertanian Bogor.

12. Asril, M., \& Leksikowati, S. S. (2019). Isolasi dan seleksi bakteri proteolitik asal limbah cair tahu sebagai dasar penentuan agen pembuatan biofertilizer. Elkawnie Journal of Islamic Science and Technology, 5(2), 86-99. DOI: $10.22373 /$ ekw.v5i2.4356

13. Lelliot, Stead. (1987). Methods for the Diagnosis of Bacterial Disease of Plants. Oxford: Blackwell Sci. Pub.

14. Prasetyo, B. H., \& Suriadikarta, D. A. (2006). Karakteristik, potensi, dan teknologi pengelolaan tanah ultisol untuk pengembangan pertanian lahan kering di Indonesia. Jurnal Litbang Pertanian, 25(2), 39-47.

15. Hasanudin \& Gonggo, B. M. (2004). Pemanfaatan mikrobia pelarut fosfat dan mikoriza untuk perbaikan fosfor tersedia, serapan fosfor tanah (ultisol) dan hasil jagung (pada ultisol). Jurnal IImu-IImu Pertanian Indonesia, 6(1), 8-13.

16. Widawati, S. (2015). Isolasi dan aktivitas Plant Growth Promoting Rhizobacteria (Rhizobium, Azospirillum, Azotobacter, Pseudomonas) dari tanah perkebunan Karet, Lampung. Berita Biologi, 14(1), 77-88.

17. Goswami, G., Deka, P., Das, P., Bora, S. S., Samanta, R., Boro, R. C., \& Borooah, M. (2017). Diversity and functional properties of acid-tolerant bacteria isolated from tea plantation soil of assam. 3 Biotech, 7(229), 116

18. Costa, R., Salles, J. F., Berg, G., \& Smalla, K. (2006). Cultivation-independent analysis of pseudomonas species in soil and in the rhizosphere of field-grown Verticillium dahlia host plants. Environmental Microbiology, 8(12), 2136-2149.

19.Sumarni, A., Aiyen, \& Panggeso, J. (2015). Pseudomonas sp. strain DSMZ 13134 dan efektivitasnya pada pertumbuhan tanaman tomat (Lycopersicum esculentum Mill.) serta serapan $P$ pada tanah masam. e-J. Agrotekbis, 3(3), 338-344.

20.Suyono, Y., \& Salahudin, F. (2011). Identifikasi dan karakterisasi Pseudomonas pada tanah yang terindikasi terkontaminasi logam. Jurnal Biopropal Industri, 2(1): 8-13.

21. Gerbeva, P., Van Veen, J. A., \& Van Elsas, J. K. (2004). Assesment of the diversity and antagonism towards rhizoctonia solani ag3, of pseudomonas species in soil from different agricultural regimes. FEMS Microbiology Ecology, 47, 51-64.

22. Latupapua, HJD., \& Nurhidayat, N. (2003). Isolasi dan Identifikasi Pseudomonas dari tanah kebun biologi Wamena dan uji awal sebagai agen biokontrol Fusarium. Berita Biologi, 6(5): 649-653.

23. Marista, E., Khotimah, S., \& Linda, R. (2013). Bakteri pelarut fosfat hasil isolasi dari tiga jenis tanah rizosfer tanaman pisang nipah (Musa paradisiacal var. nipah) di Kota Singkawang. Jurnal Protobiont, 2(2): 93-101.

24. Sagervanshi, A., Kumari, P., And, A. N., \& Kumar, A. (2012). Media Optimization for inorganic phosphate solubilizing bacteria isolated from anand agriculture soil. International Journal of Life Science \& Pharma Research, 2(3), 245-255.

25. Ramirez-Bahena, M., Cuesta, M. J., FloresFelix, J. D. Mulas, R., Rivas, R., Castro-Pinto, J., Branas, J., Mulas, D., Gonzales-Andres, F., Velazquez, E., \& Peix, A. (2014). Pseudomonas helmanticensis sp. nov., isolated from forest soil. International Journal of Systematic and Evolutionary Microbiology, 64, 2338-2345.

26. Reyes, V. A., \& Valduz, Z. (2006). Phosphate solubilizing microorganisms isolated from the rhizospheric and bulk soils of colonizer plants at an abandoned rock phosphate mine. Plant Soil, 287, 69-75.

27.Kumar, A., Kumar, A., Devi, S., Patil, S., Payal, C.,\& Negi, S. (2012). Isolation, screening and characterization of bacteria from rhzospheric soils for different plant growth promotion (PGP) activities: an in vitro study. Recent Research in Science and Technology, 4(1), 1-5.

28. Parani, K., \& Saha, B. K. (2012). Prospects of using phosphate solubilizing Pseudomonas as bio fertilizer. European Journal of Biological Sciences, 4(2), 40-44.

29. Noori, M. S. S., \& Saud, H. M. (2012). Potential plant growth-promoting activity of Pseudomonas sp. isolated from paddy soil in Malaysia as biocontrol agent. Journal of Plant Pathology and Microbiology, 3(2), 1-4.

30. Susilowati, D. N., Sudiana, I. M., Mubarik, N. R. \& Suwanto, A. (2015). Species and functional diversity of rhizobacteria of rice plant in the coastal soils of Indonesia. Indonesian Journal of Agricultural Science, 16(1), 39-50.

31. Purwaningsih, S. (2012). Isolasi, populasi dan karakterisasi bakteri pelarut fosfat pada 
daerah perakaran dan tanah dari Bengkulu, Sumatera. Jurnal Teknologi Lingkungan, 13(1), 101-108.

32.Supriadi, Nildar, I., \& Taryono. (2002). Karakterisasi Erwinia chrysanthemi penyebab penyakit busuk bakteri pada daun lidah buaya
(Aloe vera). Jurnal LITTRI (Penelitian Tanaman Industri), 8(2), 45-48.

33. Oviana, T., Aeny, T.N., \& Prasetyo, J. (2015). Isolasi dan karakterisasi penyebab penyakit busuk pada tanaman nanas (Ananas comosus (L.) Merr.). Jurnal Agrotek Tropika, 3(2), 220-225. 